\title{
Short Tandem Repeat Typing Using Endogenous DNA Isolated from Human Fingernail
}

\author{
Miriam Jasim Shehab \\ Forensic DNA Research and Training Center, Al-Nahrain University, Baghdad-Iraq. \\ Corresponding Author: miriam291083@gmail.com.
}

\begin{abstract}
Genomic DNA was isolated from variable biological sources. Nails contain genomic DNA but there is limitation in isolating of genetic material from this tissue due to the special composition and structure of this tissue in which DNA embedded in keratinized cells. This study aimed to investigate the capability of using DNA that isolated from fingernails in forensic analysis. Thirty fingernails clipping were collected from three groups (10 fingernail samples for children, 10 fingernail samples for adolescent and 10 fingernail samples for adult) in addition to thirty buccal swabs collected from the same volunteers as reference samples. Both fingernail clipping and buccal swabs were subjected to DNA extraction using phenol/chloroform extraction. All samples were typed for fifteen autosomal STR loci along with amelogenin, using the Applied Biosystems AmpFiSTR ${ }$ Identifiler ${ }^{\mathrm{TM}} \mathrm{kit}$. Our finding showed that input of $5 \mathrm{mg}$ nail material ( 1 to 2 of fingernail clippings) gives a variable yield of DNA concentration also there was no significant difference in The mean of concentration for samples that isolated from whole fingernail and those isolated from fingernail after cut into small pieces for children groups while there were significant difference for adult and adolescent groups $(0.107702,0.07544$ and 0.000192 respectively). Also the allele's percentage of STR profiles for three age groups was fluctuated among $(100,33.3,53.3,66.6,73.3,86.6$, and 93.3\%). [DOI: 10.22401/JUNS.21.1.16]
\end{abstract}

Keyword: Genomic DNA, Fingernail, DNA analysis, Allele percentage, STR profile.

\section{Introduction}

Deoxyribonucleic acid (DNA) profiling is an effective technique for human identification and/ or the resolution of criminal and civil legal disputes. One force characteristic of DNA profiling is that it may be used in assortment of various biological sources. Some of these sources include blood [1,2], semen[3], hair[4-6], saliva[7],bone[8-14] and teeth [1517]. DNA profiling of individuals with short tandem repeat (STR) markers is commonly used in forensic genetics and paternity testing. Short tandem repeats are non-coding regions of DNA used for forensic identification due to the variation between individual found in these regions [18]. They occupy about $3 \%$ of the human genome and occur on every 10,000 nucleotides [19]. Nail, hair, horn and feather (keratinous tissues) have been utilized as a source of genetic material for over 20 years. There are particular benefits of using keratinous tissues include the ease obtaining of the sample and the relative stability of DNA in these tissues [20]. Many studies have confirmed that nails are suitable for analysis
[21-23], but their use as a provenance of DNA in the forensic field is rather rare. The aim of the present study was to verify whether human nails are appropriate for personal identification and paternity testing.

\section{Materials and Methods Samples}

Thirty fresh human fingernails were obtained from random volunteers an age average (8-60). Thirty buccal swabs were also collected from same volunteers and used as reference samples. Fingernails were subjected to two different treatments. In the first treatment DNA was isolated from whole fingernail clipping while in the second treatment fingernail clipping was cut into small pieces to increase surface area exposed to lysis solution.

\section{DNA Extraction}

DNA was extracted from fingernail samples using organically after a modification of a previously published protocol [21] and buccal swab samples were extracted according to Souvik et.al. 2013 [24]. To remove the 
possible exogenous material, the nail clipping were placed in a 2-mL Eppendorf tube, washed with $500 \mu 1$ lysis solution, $10 \mu \mathrm{l}$ of $20 \mathrm{mg} / \mathrm{ml}$ protenase $\mathrm{K}$ and $3 \mu \mathrm{l}$ dithiothreitol of $1 \mathrm{M}$ and incubated in a thermomixer at $56^{\circ} \mathrm{C}$ for 1 hour, then rinsed twice with doubledistilled water. After that the samples were put on clean sterile paper to dry. Later fingernail clipping transfered to new clean 2-mL Eppendorf tube and incubated with $500 \mu 1$ lysis solution, $20 \mu \mathrm{l}$ proteinase $\mathrm{K}$ and $25 \mu \mathrm{l}$ dithiothreitol and incubate at room temperature for 24-48 hours. Subsequent steps were performed according to a standard phenol/chloroform extraction, followed by ethanol precipitation.

\section{Measuring DNA concentration and purity}

Both concentrations and purity of the extracted DNA samples were determined using nanodrop ND-1000 spectrophotometer (Nano Drop) Technologies. Also, the extracted DNA samples were electrophoresed on $1 \%$ agarose gel for checking the presences and integrity of DNA.

\section{PCR amplification}

Autosomal STR loci were typed along with amelogenin locus on the $\mathrm{X}$ and $\mathrm{Y}$ chromosomes utilizing the Applied Biosystems AmpFiSTR ${ }^{\circledR}$ Identifiler ${ }^{\mathrm{TM}}$ kit which amplifies fifteen loci: D8S1179, D21S11, D7S820, CSF1PO, D3S1358, TH01, D13S317, D16S539, D2S1338, D19S433, VWA, TPOX, D18S51, D5S818, FGA. The amplification was done by thermocycler (Applied Biosystems) [25]. One (ng) of target DNA submitted to the protocols described in the User's Manual (Applied Biosystems). The PCR conditions for amplification of STR markers were $95^{\circ} \mathrm{C}$ for $11 \mathrm{~min}, 94^{\circ} \mathrm{C}$ for 1 $\min , 59^{\circ} \mathrm{C}$ for $1 \mathrm{~min}, 72^{\circ} \mathrm{C}$ for $1 \mathrm{~min}$ and $60^{\circ} \mathrm{C}$ for $6 \mathrm{~min}$ for 28 cycles [26].

\section{DNA Typing}

Amplicons were diluted with factor 9.5: 0.5 in Hi- $\mathrm{Di}^{\mathrm{TM}}$ formamide and GS500-LIZ internal size standard (Applied Biosystems) and analyzed on the 16-capillary 3130XL Genetic Analyzer. POP'M 4 (Applied Biosystems) was used for high resolution separations on a $36 \mathrm{~cm}$ array [27].

\section{Data collection}

Specimens were analyzed by Gene Mapper v.3.2 software (Applied Biosystems, Foster City, CA, USA) after data collection was performed with Data Collection v.2.0 software (Applied Biosystems, Foster City, CA, USA).

\section{Results and Discussion}

This study was conducted to assess the isolation of Genomic DNA from fingernail clipping samples and the capability of using in forensic analysis. Samples were obtained from three age groups (children, adolescent and adult). Fingernail clipping samples were washed to exclude contamination which inhibits polymerase chain reaction. Our results show that the DNA yield for samples that used whole nail clipping $(5 \mathrm{mg})$ rang between $(40-144 \mathrm{ng} / \mu \mathrm{l})$. The mean of DNA concentration for children group was $126.2 \pm$ 12.35718, while was $70.8 \pm 14.42914$ for adolescent group and $52 \pm 8.860023$ for adults while DNA yield for samples that use small pieces of nail clipping (5mg) rang between (8$66 \mathrm{ng} / \mu \mathrm{l})$ and the mean for three age groups were $57.2 \pm 6.760178,34 \pm 6.63325$ and $18.2 \pm$ 6.797058 respectively Table (1). These quantities are considered to be good if it is aimed to be used in personal identification and paternity testing since the quantity of required DNA in polymerization is not less than $0.5 \mathrm{ng}$. Also there was no significant difference in The mean of concentration for samples that isolated from whole fingernail and those isolated from fingernail after cut into small pieces for children groups while there were significant difference for adult and adolescent groups $(0.107702,0.07544$ and 0.000192 respectively). The variability in DNA yields is not entirely clear, but it might be related to the different keratin content that strongly affects the weight of nail material. A standardized of nail clippings may therefore contain a variable number of cell nuclei or possibly extra nuclear DNA, leading to fluctuating levels of extractable DNA [30].

The purity of nail clipping samples ranged between $(1.3$ - 1.6) which was lower than the ratio A260/A280 of pure double-stranded DNA which is 1.8. This could be due to contamination of the samples with proteins (e.g., keratin) and phenol. 
Result of agarose gel electrophoresis descriptive of the quality and integrity of the extracted DNA, our investigation showed that the DNA extracted from buccal swab appeared sharp band while DNA isolated from fingernails clipping were highly fragmented Fig.(1) this result agree with other studies $[28,29]$. Genetic material in nail creates from germinal matrix cells in the nail root. During growth, germinal matrix cells differentiate into nail plate and are filled with keratin. In this stage of keratinization, the cells suffer programmed cell death, which lead to considerable DNA fragmentation [20]. Table (2) illustrates the percentage of STR loci which emerged for each profile obtained from fingernail clipping. Short tandem repeat (STR) use in forensic field to estimates specific marker that are found on nuclear DNA. The variable nature of (STR) regions make the probability of similarity among individuals in 13 loci of DNA profile can be as high as 1 in 1 billion or greater (except identical twins). In this study genetic profile typed from each fingernail sample was identical with buccal swab sample to the same individual. the percentage of STR loci were $100 \%$ for all DNA samples extracted from buccal swab while this percentage Fluctuated and some loci were drop-out in respect to DNA samples that isolated from nail clipping Fig.(2) clarifies successful amplification for all STR loci get from nail material.

Table (1)

Concentration of DNA extracted from $5 \mathrm{mg}$ of fingernail.

\begin{tabular}{|c|c|c|c|c|c|c|c|}
\hline \multirow{2}{*}{$\begin{array}{l}\text { Age } \\
\text { Year }\end{array}$} & \multicolumn{3}{|c|}{ Whole fingernail (5mg) } & \multicolumn{3}{|c|}{ Small fingernail pieces (5mg) } & \multirow[b]{2}{*}{ P value } \\
\hline & $\begin{array}{c}\text { Quantity of DNA } \\
\text { (ng) }\end{array}$ & mean & $\begin{array}{l}\text { Standard } \\
\text { Deviation }\end{array}$ & $\begin{array}{l}\text { Quantity of } \\
\text { DNA (ng) }\end{array}$ & Mean & $\begin{array}{l}\text { Standard } \\
\text { Deviation }\end{array}$ & \\
\hline \multirow{5}{*}{$(8-15)$} & 111 & \multirow{5}{*}{126.2} & \multirow{5}{*}{12.35718} & 49 & \multirow{5}{*}{57.2} & \multirow{5}{*}{6.760178} & \multirow{5}{*}{0.107702} \\
\hline & 125 & & & 66 & & & \\
\hline & 144 & & & 60 & & & \\
\hline & 131 & & & 59 & & & \\
\hline & 120 & & & 52 & & & \\
\hline \multirow{5}{*}{$(16-39)$} & 62 & \multirow{5}{*}{70.8} & \multirow{5}{*}{14.42914} & 39 & \multirow{5}{*}{34} & \multirow{5}{*}{6.63325} & \multirow{5}{*}{0.007544} \\
\hline & 57 & & & 25 & & & \\
\hline & 93 & & & 37 & & & \\
\hline & 77 & & & 40 & & & \\
\hline & 65 & & & 29 & & & \\
\hline \multirow{5}{*}{$(40-60)$} & 54 & \multirow{5}{*}{52} & \multirow{5}{*}{8.860023} & 16 & \multirow{5}{*}{18.2} & \multirow{5}{*}{6.797058} & \multirow{5}{*}{0.000192} \\
\hline & 46 & & & 8 & & & \\
\hline & 61 & & & 19 & & & \\
\hline & 40 & & & 22 & & & \\
\hline & 59 & & & 26 & & & \\
\hline
\end{tabular}




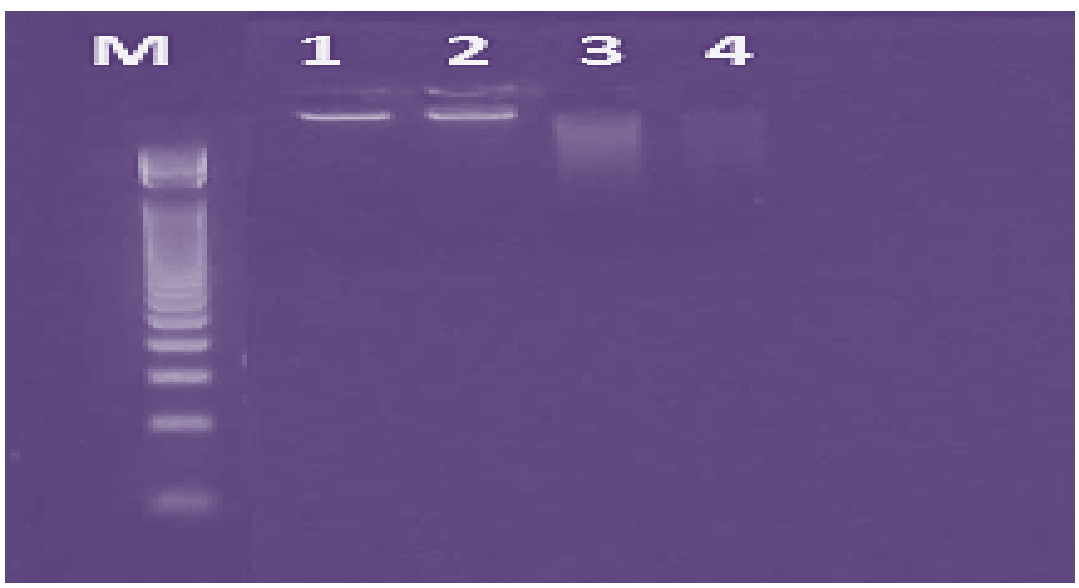

Fig.(1): Gel electrophoresis analysis of genomic DNA on $1 \%$ agarose gel stained with red safe DNA dye and electrophoresed at 5 volt /cm for 45 minutes and visualized under UV light. DNA maker $50 \mathrm{bp}$, the lane $(1,2)$ represent DNA extracted from buccal swab samples and the lane $(3,4)$ represent DNA extracted from fingernail clipping samples.

Allele drop-out happens when one or more alleles are not present after sample is typed with STR marker. This may be due to more than one reason: a mutation in the primer binding site is present which causes a failure in the amplification of the allele, the initial input quantity of DNA is too low resulting in the failure to amplify one or more alleles in the sample, an allele sizes outside of the normal calling range for a particular locus and goes undetected. Furthermore, allele drop-out occurs due to polymerase chain reaction

Table (2)

The relationship among quantity of DNA isolated from fingernail, concentration utilized in polymerase chain reaction and allele's percentage of STR profile for three age groups.

\begin{tabular}{|c|c|c|c|c|c|c|c|c|}
\hline $\begin{array}{c}\text { Age } \\
\text { group } \\
\text { year }\end{array}$ & $\begin{array}{l}\text { Quantity of } \\
\text { DNA (ng) }\end{array}$ & $\begin{array}{c}\text { Concentration } \\
\text { of DNA }(\mathrm{ng} / \mu \mathrm{l})\end{array}$ & $\begin{array}{c}\text { Quantity of } \\
\text { DNA utilizes in } \\
\text { PCR (ng) }\end{array}$ & $\begin{array}{c}\text { Appearance } \\
\text { of alleles } \\
(\%)\end{array}$ & $\begin{array}{c}\text { Quantity } \\
\text { of DNA } \\
\text { (ng) }\end{array}$ & $\begin{array}{l}\text { Concentration of } \\
\text { DNA }(n g / \mu l)\end{array}$ & $\begin{array}{l}\text { Quantity of } \\
\text { DNA utilizes } \\
\text { in PCR (ng) }\end{array}$ & $\begin{array}{c}\text { Appearance } \\
\text { of alleles } \\
\%\end{array}$ \\
\hline \multirow{5}{*}{$(8-15)$} & 111 & 2.22 & 22.2 & 100 & 49 & 0.98 & 9.8 & 53.3 \\
\hline & 125 & 2.5 & 25 & 100 & 66 & 1.32 & 13.2 & 86.6 \\
\hline & 144 & 2.88 & 28.8 & 93.3 & 60 & 1.2 & 12 & 100 \\
\hline & 131 & 2.62 & 26.2 & 100 & 59 & 1.18 & 11.8 & 86.6 \\
\hline & 120 & 2.4 & 24 & 86.6 & 52 & 1.04 & 10.4 & 100 \\
\hline \multirow{5}{*}{ (16-39) } & 62 & 1.24 & 12.4 & 100 & 39 & 0.78 & 7.8 & 100 \\
\hline & 57 & 1.14 & 11.4 & 100 & 25 & 0.5 & 5 & 73.3 \\
\hline & 93 & 1.86 & 18.6 & 93.3 & 37 & 0.74 & 7.4 & 100 \\
\hline & 77 & 1.54 & 15.4 & 100 & 40 & 0.8 & 8 & 66.6 \\
\hline & 65 & 1.3 & 13 & 100 & 29 & 0.58 & 5.8 & 100 \\
\hline \multirow{5}{*}{$(40-60)$} & 54 & 1.08 & 10.8 & 100 & 16 & 0.32 & 3.2 & 60 \\
\hline & 46 & 0.92 & 9.2 & 73.3 & 8 & 0.16 & 1.6 & 33.3 \\
\hline & 61 & 1.22 & 12.2 & 100 & 19 & 0.38 & 3.8 & 60 \\
\hline & 40 & 0.8 & 8 & 100 & 22 & 0.44 & 4.4 & 53.3 \\
\hline & 59 & 1.18 & 11.8 & 100 & 26 & 0.52 & 5.2 & 73.3 \\
\hline
\end{tabular}


Each nucleated cell contains two copies of an individual's genome and can be used to generate a DNA profile under optimal conditions [32]. DNA can be isolated substantially from any part of human body. The most common source of DNA is blood, also DNA can be extracted from saliva, semen, hair root and even from several skin cell left on surface of glass after it was touch [33]. Several studies have reported that the fresh or old nail can be used as a source for nuclear DNA and mitochondrial DNA [34, 21, 22, 35]. Isolating genetic material from keratinous tissues (nails) are more difficult than from body fluids or soft tissues due to the washing steps for removing exogenous material, possible nail polish and the incubation step to dissolve the nail material. On the other hand, nail samples are the lowest costs for obtaining and storing, least invasive and most suitable for use in pediatric studies. [28].

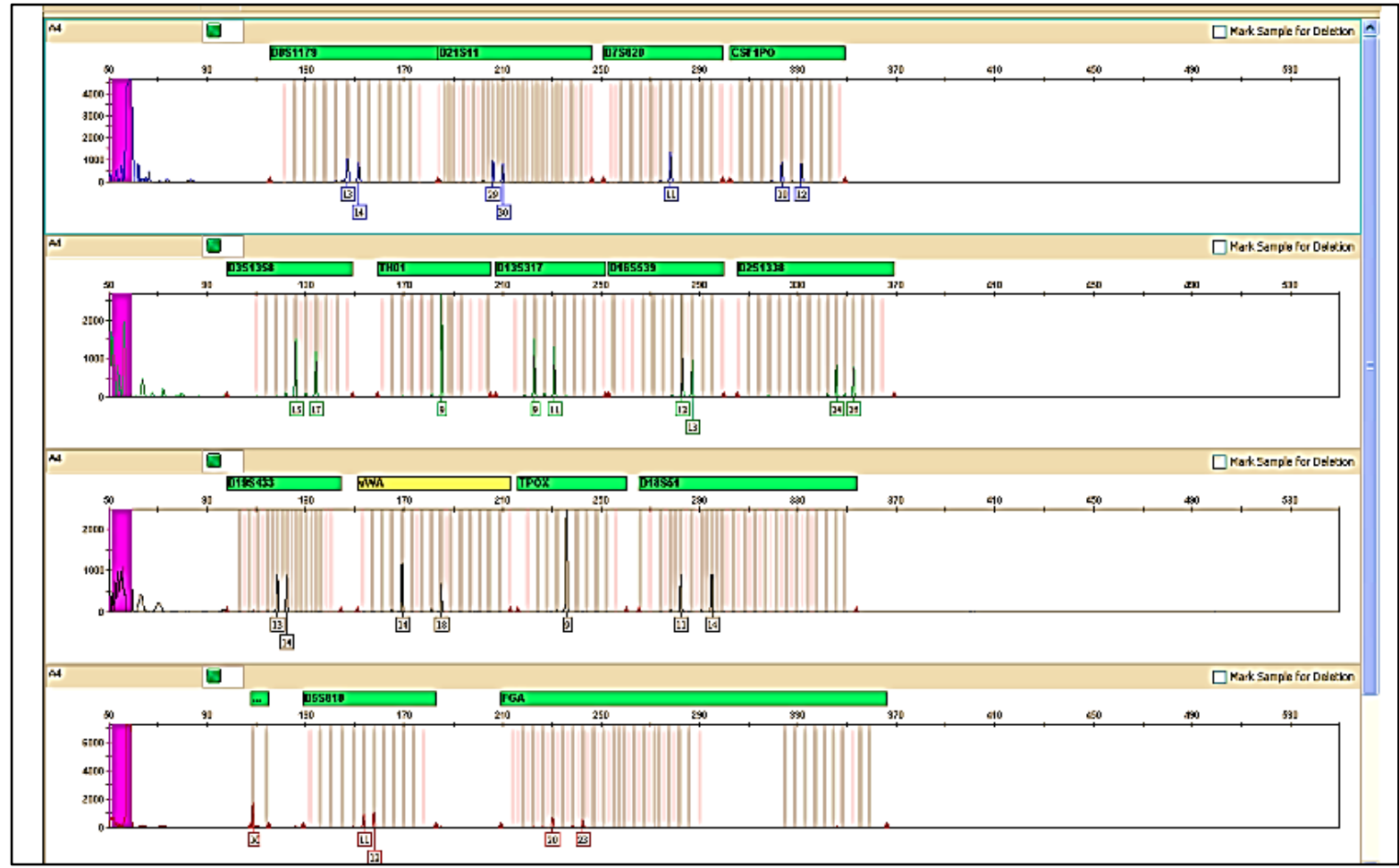

Fig.(2): Electropherogram of DNA profile obtained from fingernail clipping amplified with 16 loci of STR. It can be seen the amplification was successful.

\section{Conclusion}

In recent years obtaining genomic DNA in an easy way is an issue of importance. Although the genetic material that extracted from fingernail specimens have fragmented nature and relatively high contaminants due to the special composition and structure of keratinous tissue in which DNA embedded in keratinized cells that limit isolated DNA in sufficient quantity and high quality nails are considered alternative source of DNA especially when the purpose of its use in forensic analysis.

\section{References}

[1] Jung JM., Comey CT, bear DB, Budowle B. "Extraction strategy obtaining DNA fom blood stains for PCR amplification and typing of HLA-DQ gene", Int J Leg Med 104-45, 1991.

[2] Kanter E, Baird M, Shaler R., Balazs I. "Analysis of restriction fragment length polymorphism in Deoxyribonucleic acid 
(DNA) recovered from dried blood stains". J Forensic Sci, ( 31-403), 1986.

[3] Giusti A., Baird M., Pasqual M, Balazs I., Glassberg J. "Application of Deoxyribonucleic acid (DNA) polymorphism to the analysis of DNA recovered from sperm”. J Forensic Sci, (31-409), 1986.

[4] Higuchi R., Von Beroldingen $\mathrm{CH}$, Sensabaugh GF, Erlich HA. "DNA typing from single hair”.Nature, 332(543-6), 1988.

[5] Uchihi R., Tamaki K., Kojima T., Yamamoto T., Katsumata Y. "Deoxyribonucleic acid (DNA) typing of human leukocyte antigen (HLA)-DQAI from single hair in Japanese". J Forensic Sci, 37(853-9), 1992.

[6] Wilson M.R., Polanskey D., Butler J., Dizinno J.A., Repogle J., Budowle B. "Extraction, PCR amplification and sequencing of mitochondrial DNA from human hair shafts". Biotechniques, 18(6626), 1995.

[7] Walsh D.J., Corey A.C., Cotton R.W., Forman L., Herrin G.L., Word C.J., et al. "Isolation of Deoxyribonucleic acid (DNA) from saliva and forensic science samples containing saliva". J Forensic Sci, 37(38795), 1992.

[8] Fisher D.L., Holland M.M., Mitchell L., Sledzik P.S., Wilcox A.W., Wadhams M., et al. "Extraction, evaluation and amplification of DNA from decalcified and undecalcified united states civil war bone". J Forensic Sci, 38(60-8), 1993.

[9] Hochmeister M.N., Budowle B., Borer U.V., Eggmann U., Comey C.T., Dirnhofer R. "Typing of Deoxyribonucleic acid (DNA) extracted from copact bone from human remains". J Forensic Sci, 36(164961), 1991.

[10] Holland M.M., Fisher D.L., Mitchell L.G., Rodriguez W.C., Canik J.J., Merril C.R., et al. "Mitochondrial DNA sequence analysis of human skeletal remains: identification of remains from the Vietnam war". J Forensic Sci, 38(542-53), 1993.

[11] Lee H.C., Pagliaro E.M., Berka K.M., Folk N.L., Anderson D.T., Ruano G., et al. "Genetic markers in human bone: I. Deoxyribonucleic acid (DNA) analysis". J Forensic Sci, 36(320-30), 1991.
[12] Lee H.C., Pagliaro E.M., Gaensslen R.E., Berka K.M., Keith T.P., Keith G.N., et al. "DNA analysis in human bone tissue: RFLP typing". J Forensic Sci, 31(209-12), 1991.

[13] Lee H.C., Ruano G., Pagliaro E.M., Berka KM, Gaensslen R.E. "DNA analysis in human bone and other specimens of forensic interest: PCR typing and testing". J Forensic Sci, 31(21-6), 1991.

[14] Parson T.J., Weedn V.W. "Preservation and recovery of DNA in postmortem specimens and trace sample. Forensic taphonomy: the postmortem fate of human remains". CRC press 1997.

[15] Putsch L., Meyer U., Rothschild S., Schneider P.M., Rittner C. "application of DNA techniques for identification using human dental pulp as a source of DNA". Int Leg Med, 105(139- 43), 1992.

[16] Schwartz T.R., Schwartz E.A., Mieszerski L., McNally L., Kobilinsky L. "Characterization of Deoxyribonucleic acid (DNA) obtain from teeth subjected to avarious environmental conditions". J Forensic Sci, 36(979-90), 1991.

[17] Smith B.C., Fisher D.L., Weedn V.W., Warnock G.R., Holland M.M. "A systematic approach to sampling of dental DNA”. J Forensic Sci, 38(1194- 209), 1993.

[18] Jeffreys A., Wilson V. and Thein S. "Hypervariable minisatellite regions in human DNA", Nature, 314(67-73), 1985.

[19] Butler J., "Forensic DNA Typing: Biology, Technology, and Genetics of STR Markers", $2^{\text {nd }}$ Edn., Elsevier, Burlington, (660), 2005.

[20] Bengtsson C.F., Olsen M.E., Brandt L.O., Bertelsen M.F., Willerslev E, Tobin DJ, et al. DNA from keratinous tissue. Part I: hair and nail. Ann Anat 2012;194:17-25.

[21] Tahir M.A., Watson N. "Typing of DNA HLA-DQ alpha alleles extracted from human nail material using polymerase chain reaction", J Forensic Sci, 40(4), 634-6, 1995.

[22] Anderson T.D., Ross J.P., Roby R.K., Lee D.A., Holland M.M. "A validation study for the extraction and analysis of DNA from human nail material and its application to forensic casework", J Forensic Sci, 44(5), 1053-6, 1999. 
[23] Tahir M.A., Balraj E., Luke L., Gilbert T., Hamby J.E., Amjad M. "DNA typing of samples for polymarker, DQA1, and nine STR loci from a human body exhumed after 27 years", J Forensic Sci, 45(4), 902-7, 2000.

[24] Souvik Ghatak, Rajendra Bose Muthukumaran, Senthil Kumar Nachimuthu. "A Simple Method of Genomic DNA Extraction from Human Samples for PCR-RFLP Analysis”. Journal of Bimolecular technioques, 24(4), 2013.

[25] User's Manual Applied Biosystems, AmpFISTR ${ }^{\circledR} \quad$ Identifiler® Plus PCR Amplification Kit, Applied Biosystems. Thermo Fisher Scientific, 2015.

[26] Schneider P.M., Martin P.D. Criminal DNA databases: "the European situation". Forensic Sci Int, 119, 232-238, 2001.

[27] Applied Biosystems. AmpFISTR Identifiler PCR Amplification Kit User's Manual, Foster City, CA. 4323291, 2001.

[28] Hogervorst J.G., Godschalk R.W., van den Brandt P. A., Weijenberg M. P., Verhage B. A., Jonkers L., Goessens J., Simons C.C., Vermeesch J. R., Schooten F. J., and Schouten L. J. "DNA from Nails for Genetic Analyses in Large-Scale Epidemiologic Studies Cancer Epidemiol Biomarkers", Prev,23(12), 2703-12, 2014.

[29] Tanigawara Y., Kita T., Hirono M., Sakaeda T., Komada F., Okumura K. "Identification of $\mathrm{N}$-acetyltransferase 2 and CYP2C19 genotypes for hair, buccal cell swabs, or fingernails compared with blood". Ther Drug Monit, 23, 341-346, 2001.

[30] Preuner S., Danzer M., Pröll J., Pötschger U., Lawitschka A., Gabriel C., and Lion T. "High-Quality DNA from Fingernails for Genetic Analysis". The Journal of Molecular Diagnostics, 16(4), 459-466, 2014.

[31] Bessetti, J. "An Introduction to PCR Inhibitors", 2001, Retrieved from http://www.promega.com/ /media/files/reso urces/profiles in dna/1001/an introduction to pcr inhibitors.pdf.

[32] Castella, V. et al. "Forensic evaluation of the QIAshredder/QIAamp DNA extraction procedure". Forensic Science International, 156, 70-73, 2006.
[33] Greenspoon, S.A. et al. "Application of the BioMek (R) 2000 laboratory automation workstation and the DNAIQ (TM) system to the extraction of forensic casework samples". Journal of Forensic Sciences 49, 29-39, 2004.

[34] Kaneshige T., Takagi K., Nakamura S., Hirasawa T., Sada M., Uchida K. "Genetic analysis using fingernail DNA". Nucleic Acids Res, 20, 5489-90, 1992.

[35] Cervantes J. "HLA class II allele typing using DNA obtained from human fingernail clipping material". Rev Invest Clin, 56, 341-344, 2004. 